\begin{tabular}{|l|lll|}
\hline & Journal : Small 10526 & Dispatch : 10-10-2007 & Pages : 22 \\
& Article No. : 9125 & $\square$ LE & $\square$ TYPESET \\
MS Code : BICO632 & $\checkmark \mathrm{CP}$ & $\checkmark$ DISK \\
\hline
\end{tabular}

\title{
3 Intraguild predation involving Harmonia axyridis: 4 a review of current knowledge and future perspectives
}

\author{
5 Judith K. Pell · Jason Baverstock $\cdot$ Helen E. Roy • Remy L. Ware • \\ 6 Michael E. N. Majerus
}

7 Received: 10 August 2007/ Accepted: 8 October 2007

8 C International Organization for Biological Control (IOBC) 2007

9 Abstract As an effective generalist predator of aphids and other hemipteran pests

$10 \quad H$. axyridis has been a successful biological control agent. However, the very functional

11 traits that have contributed to its success in this regard also implicate it as an intraguild

12 predator that poses a significant risk not only to the diversity of other natural enemies of

13 Hemiptera (and their associated ecosystem services), but to biodiversity more widely. In

14 this paper we will specifically review the existing data on intraguild predation involving

$15 H$. axyridis, and consider the strength and symmetry of such interactions both within its

16 native guild and within exotic guilds where it has established as an invasive alien. We will

17 use these studies to interpret the observed population declines in predator diversity in the

18 field, predict species at risk in regions not yet invaded and consider implications for

19 resulting ecosystem services. We will also indicate gaps in our knowledge that require

20 further study in order to identify opportunities for mitigation.

21 Keywords Coccinellidae $\cdot$ Harmonia axyridis Aphidophagous guild ·

22 Intraguild predation · Predators · Parasitoids · Pathogens · Ecosystem services

\section{Introduction}

Terrestrial ecosystems support a diversity of species that are directly and indirectly linked to each other within food webs that span multiple trophic levels. Natural enemy species (in the context of this paper we will collectively call these 'predators' as they all have a trophic relationship with their hosts/prey) contribute to the population regulation of species in both

J. K. Pell $(\triangle)$. J. Baverstock

A2 Department of Plant and Invertebrate Ecology, Rothamsted Research, Harpenden, Hertfordshire

A3 AL5 2JQ, UK

A4 e-mail: judith.pell@bbsrc.ac.uk

H. E. Roy

A6 Biological Records Centre, CEH Monks Wood, Abbots Ripton, Huntingdon PE28 2LS, UK

A7 R. L. Ware - M. E. N. Majerus

A8 Department of Genetics, University of Cambridge, Downing Street, Cambridge CB2 3EH, UK 


\begin{tabular}{|l|lll|}
\hline & Journal : Small 10526 & Dispatch : $\mathbf{1 0 - 1 0 - 2 0 0 7}$ & Pages : 22 \\
& Article No. : 9125 & $\square$ LE & $\square$ TYPESET \\
MS Code : BICO632 & $\checkmark$ CP & $\checkmark$ DISK \\
\hline
\end{tabular}

J. K. Pell et al.

the same and lower trophic levels (top down pressure) and in this way influence the structure of the community as a whole. In the case of aphids these natural enemies (aphidophages) include specialist and generalist predators, parasitoids and pathogens (Völkl et al. 2007). Together they represent a 'guild', i.e., a community of species that share the same host/prey resource (Polis et al. 1989; Rosenheim et al. 1995). As aphids are often pests in managed ecosystems these natural enemies provide a valuable pest management ecosystem service that can be manipulated within biological control strategies (e.g., Barbosa 1998; Gurr et al. 2004; Losey and Vaughan 2006; Powell and Pell 2007; Pell 2008).

Different 'predator' taxa play different ecological roles within the guild (Rosenheim et al. 2004a). 'Intermediate predators' function from the third trophic level suppressing herbivores, whereas 'top predators' mainly operate from the fourth trophic level suppressing 'intermediate predators' and, consequently, releasing herbivore populations from control (Polis 1994; Rosenheim 1998). Intraguild predation occurs when one of two species competing for the same host/prey also consumes its competitor, and can be a strong force structuring communities. Omnivorous intraguild predation can be asymmetric when one of the two species (the intraguild predator) always preys on the other (the intraguild prey), or symmetric when both species prey on each other to a greater or lesser extent (Polis et al. 1989; Polis and Holt 1992; Rosenheim et al. 1995). The intraguild predator benefits not only from the nutritive value of the meal, but also from the removal of a competitor. Coincidental intraguild predation occurs when a parasitoid or pathogen is consumed while still developing within its herbivore host and, in this case, the herbivore and the intraguild prey are directly linked (Polis et al. 1989). Intraguild predators function as both 'intermediate' and 'top predators' by feeding on both herbivores and 'intermediate predators'.

The impact of intraguild predation on community structure and diversity can be extremely variable, complex and difficult to predict (Rosenheim et al. 2004a; Snyder and Evans 2006; Straub et al. 2008). Many studies have assessed the prevalence of intraguild predation in aphidophagous guilds (Polis et al. 1989; Rosenheim et al. 1995; Holt and Polis 1997; Müller and Brodeur 2002; Lucas 2005; Pell 2008) and reported it to be a widespread phenomenon with implications for both predator diversity within the guild and the pest management ecosystem services that the guild delivers.

As an effective generalist predator of aphids and other hemipteran pests Harmonia axyridis (Pallas) (Coleoptera: Coccinellidae) has been widely and repeatedly augmented or introduced for biological control. As such, it has contributed significantly to pest suppression in a wide variety of managed ecosystems including pecan, apple, sweet corn, alfalfa, cotton, tobacco, wheat and soybean (Tedders and Schaefer 1994; Buntin and Bouton 1997; Brown and Miller 1998; Colunga-Garcia and Gage 1998; Wells and McPherson 1999; Wells et al. 2001; Musser and Shelton 2003; Koch 2003; Majerus et al. 2006; Roy et al. 2006). However, the very functional traits that have made $H$. axyridis an effective biological control agent, also implicate it as an intraguild predator that poses significant risk to the diversity of other natural enemies of Hemiptera and their ecosystem services. Although natural enemy diversity in its native range remains relatively stable in the presence of $H$. axyridis (Kuznetsov 1988, 1997), wherever it has established after introduction as an exotic species, it has been associated with declines in native natural enemies, particularly native coccinellids (Majerus et al. 2006; Roy et al. 2006; Snyder and Evans 2006). These declines have been attributed to direct interspecific competition for resources with less competitive/fecund natural enemies (Michaud 2002) but are also likely to be strongly influenced by its role as an intraguild predator. 


\begin{tabular}{|l|lll|}
\hline & Journal : Small 10526 & Dispatch : 10-10-2007 & Pages : 22 \\
& Article No. : 9125 & $\square$ LE & $\square$ TYPESET \\
MS Code : BICO632 & $\checkmark$ CP & $\checkmark$ DISK \\
\hline
\end{tabular}

Intraguild predation involving $H$. axyridis

There are a number of functional traits that determine the nature, symmetry and outcome of intraguild predation including: relative size (incidence of mortality is often inversely correlated with size) (Majerus 1994; Evans 2000), aggressive strategies and mandibular structure (Yasuda et al. 2001), degree of feeding and habitat specificity, mobility (sessile stages are particularly vulnerable), defence strategies and abundance of extraguild prey (Polis et al. 1989; Lucas et al. 1998; Roy et al. 2006; Straub et al. 2008). In this paper we will specifically review the existing, largely experimental, data on these traits for $H$. axyridis, and discuss their strength and symmetry both within its native guild and within exotic guilds where it has established as an invasive alien. We will use these studies to interpret the observed population declines in natural enemy diversity in the field, predict species at risk in regions not yet invaded and consider implications for resulting ecosystem services. We will also identify gaps in our knowledge that require further study in order to identify opportunities for mitigation.

\section{Current knowledge}

Intraguild predation between $H$. axyridis and coccinellids of other species

\section{Eggs}

The relative size and mobility of the intraguild predator and prey are known to influence the outcome of intraguild predation, both showing an inverse correlation with the incidence of mortality (Huey and Pianka 1981; Sengonca and Frings 1985; Rosenheim et al. 1995; Lucas et al. 1998). In coccinellids this equates to the immature stages being more vulnerable than adults, and eggs being particularly threatened (Sato and Dixon 2004; Cottrell 2007).

Harmonia axyridis adults and larvae find eggs of many insect species acceptable as prey; laboratory stocks are often maintained on eggs of the Mediterranean flour moth, Ephestia kuehniella Zeller (Lepidoptera: Pyralidae) (Berkvens et al. 2008). Cottrell (2004) reports that $H$. axyridis adults attacked eggs of Coleomegilla maculata (De Geer) (Coleoptera: Coccinellidae) and Olla v-nigrum (Mulsant) (Coleoptera: Coccinellidae) more frequently than adults of these species attacked $H$. axyridis eggs, and attest that intraguild predation of eggs is a serious threat for these species. However, cannibalism and predation of coccinellid eggs are most often associated with larval stages (Dixon 2000; Cottrell 2007) and, for some species, may be affected by the relative abundance of extraguild prey (Sato et al. 2003); at low aphid or coccid densities, coccinellid larvae are more likely to engage in cannibalism or intraguild predation. In addition, the tendency for intraguild predation by larvae varies between species both as intraguild predators and intraguild prey. Cannibalism and intraguild predation by $H$. axyridis are commonly observed, both in the laboratory and the field, even when aphids or coccids are abundant (M.E.N. Majerus and R.L. Ware personal observation). A recent study concluded that $H$. axyridis larvae were more likely to engage in intraguild predation of the eggs of C. maculata, Cycloneda munda (Say) (Coleoptera: Coccinellidae), Hippodamia convergens Guérin-Méneville (Coleoptera: Coccinellidae) and $O . v$-nigrum than for $H$. axyridis eggs to be the intraguild prey of the larvae of these species (Cottrell 2007). This is in agreement with previous work of Cottrell (2004) demonstrating that neither C. maculata nor $O$. v-nigrum larvae can complete development on $H$. axyridis eggs whereas $H$. axyridis can complete development on a diet of either C. maculata or $O$. v-nigrum eggs. 


\begin{tabular}{|l|lll|}
\hline & Journal : Small 10526 & Dispatch : 10-10-2007 & Pages : 22 \\
& Article No. : 9125 & $\square$ LE & $\square$ TYPESET \\
MS Code : BICO632 & $\checkmark$ CP & $\checkmark$ DISK \\
\hline
\end{tabular}

J. K. Pell et al.

Defensive adaptations (chemical or physical) are often effective in reducing the susceptibility of sessile life stages, such as eggs, prepupae and pupae to intraguild predation and cannibalism. The chemical defences of coccinellid eggs have been well studied (Agarwala and Dixon 1992; Hemptinne and Dixon 2000). Indeed, while intrinsic toxicity or unpalatability is governed by de novo synthesis of species-specific alkaloids (Pasteels et al. 1973; King and Meinwald 1996), Hemptinne and Dixon (2000) demonstrated the existence of extrinsic chemicals on the surface of some species' eggs that act as deterrents against intraguild predation. Ware et al. (2008b) have recently discussed the role of surface deterrents on eggs of the European species Calvia 14-guttata (L.) (Coleoptera: Coccinellidae) as a defence against intraguild predation by $H$. axyridis. A similar phenomenon has been speculated for the eggs of the Japanese species Eocaria muiri Timberlake (Coleoptera: Coccinellidae) (Ware et al. 2008a). The defensive chemistry of H. axyridis eggs themselves has been implicated as pivotal to the observed resistance of H. axyridis eggs to predation by other aphidophages that appear to find them unpalatable (Alam et al. 2002; Sato and Dixon 2004). Interestingly, similar alkanes to those found on the surface of $H$. axyridis eggs are also present in larval tracks and act as oviposition deterring semiochemicals for other ladybirds, thus reducing egg cannibalism and intraguild predation (Magro et al. 2007).

\section{Larvae and pupae}

Ware and Majerus (2008) have comprehensively examined intraguild predation of immature stages of British and Japanese coccinellids by H. axyridis. A total of 12 species of coccinellid (Coleoptera: Coccinellidae) were included in this laboratory study: eight derived from British populations (Coccinella 7-punctata L., Adalia 2-punctata (L.), Adalia 10-punctata (L.), Propylea 14-punctata (L.), C. 14-guttata, Anatis ocellata (L.), Harmonia 4-punctata (Pontoppidan), Coccinella 5-punctata L.) and four from Japanese populations (Coccinella 7-punctata brucki Mulsant, Cheilomenes 6-maculatus (Fabricius), Propylea japonica Thunberg and E. muiri). In general, $H$. axyridis was an intraguild predator of all species, with the exception of A. ocellata. The important conclusions of this study were that there was no obvious difference between the susceptibilities of Japanese and British coccinellids to intraguild predation by $H$. axyridis, and intraguild predation by $H$. axyridis represents a serious threat for many species in Britain (Ware and Majerus 2008).

The relatively large size of $H$. axyridis throughout its life cycle undoubtedly contributes to its success as an intraguild predator following the 'size matters' hypothesis. In predatory interactions between coccinellid larvae it is generally the larger that eats the smaller, assuming both are mobile (Majerus 1994). Notably, in comparative tests between fourth instar larvae of H. 4-punctata, H. axyridis and A. ocellata, which have similar behavioural and physical defences, the level of intraguild predation was directly correlated to size. Larvae of the largest species, $A$. ocellata, won the majority of encounters with $H$. axyridis, while the smallest species, H. 4-punctata, lost most such encounters (Ware and Majerus 2008).

There are few reports of other larval coccinellids successfully attacking $H$. axyridis, and most evidence suggests that the immature stages of $H$. axyridis are resistant to reciprocal attacks. In a laboratory study assessing the interactions between $H$. axyridis and C. 7-punctata, Yasuda et al. (2001) attributed the greater success of the former to its higher attack rates and greater escape ability. Recent research is beginning to confirm the importance of chemical defence of $H$. axyridis larvae as a means of preventing counter-attacks (Ware and Majerus 2008), and larvae are known to produce similar defensive alkaloids to those present 


\begin{tabular}{|l|lll|}
\hline & Journal : Small 10526 & Dispatch : 10-10-2007 & Pages : 22 \\
& Article No. : 9125 & $\square$ LE & $\square$ TYPESET \\
MS Code : BICO632 & $\checkmark$ CP & $\checkmark$ DISK \\
\hline
\end{tabular}

Intraguild predation involving $H$. axyridis

167 within eggs and released by adults (Pasteels et al. 1973; King and Meinwald 1996). Further studies have also implicated the role of superior physical defences (spines rather than hairs) in larval stages of $H$. axyridis compared to other species (Ware and Majerus 2008).

In the field, coccinellid larvae tend to disperse from a plant when prey abundance is low (Sato 2001) and this reduces the incidence of cannibalism and intraguild predation by larger larvae and adults (Sato et al. 2003). However, emigration is a precarious strategy for an immature coccinellid, so there is a trade-off between emigrating or remaining on a plant with a low prey density and risking cannibalism or intraguild predation. Harmonia axyridis commonly co-occurs with C. 7-punctata brucki and P. japonica in their native Japanese range (Yasuda and Shinya 1997; Sato 2001). In a Japanese field study of these three coccinellid species co-occurring on shrubs both C. 7-punctata brucki and H. axyridis larvae emigrated in response to low prey density whereas $P$. japonica larvae did not (Sato 2001). The prevalence of intraguild predation and cannibalism of $C$. 7-punctata brucki and $H$. axyridis larvae was low whereas no $P$. japonica larvae completed their development on the shrubs and this was assumed to be as a consequence of intraguild predation. In further studies it was confirmed that the early emigration of C. 7-punctata brucki larvae enabled them to escape from intraguild predation by $H$. axyridis larvae (Sato et al. 2003) and that the late emigration of $P$. japonica larvae accounted for the high incidence of intraguild predation by $H$. axyridis larvae (Sato et al. 2003).

Propylea japonica is also a smaller species than either H. axyridis or C. 7-punctata brucki and so this further supports the hypothesis that 'size matters' in intraguild predation. Ware and Majerus (2008) also report $P$. japonica larvae as highly palatable intraguild prey with little physical defence from attack by $H$. axyridis. It is interesting to note from field studies in Japan that $C$. 7-punctata brucki are active earlier in the spring than $H$. axyridis (Takahashi and Naito 1984; Sato 2001). Therefore, H. axyridis are more likely to experience a scarcity of aphids, which are abundant in spring and early summer, than C. 7-punctata brucki. Consequently, $H$. axyridis is likely to be more reliant on intraguild prey to complete their development than is C. 7-punctata brucki (Sato et al. 2003).

\section{Adults}

196 Adult coccinellids are generally less susceptible to predation than immature stages due to their protective elytra and aposematic colour patterns (Majerus 1994). However, they are exposed to a particularly vulnerable period just after eclosion, when their elytra are still soft. Ware and Majerus (2008) report observations of attacks made on eclosing or newly eclosed adults by larvae, when no other food was available. Fourth instar $H$. axyridis larvae were observed to attack and consume new adults of A. 10-punctata, A. ocellata, C. 14-guttata, C. 7-punctata brucki and E. muiri, after not having attacked them as pupae (Ware and Majerus 2008). However, the consumption of newly eclosed $H$. axyridis adults was rare, and only performed by conspecific larvae and larvae of the congeneric species H. 4-punctata. This supports the speculation that the defensive chemistry of $H$. axyridis adults may make them unpalatable to other coccinellids (Hough-Goldstein et al. 1996).

\section{Intraguild predation between $H$. axyridis and non-coccinellid predators}

208 Coccinellids are common within aphidophagous guilds and most studies considering the 209 role of $H$. axyridis as an intraguild predator have focussed on interactions within the 


\begin{tabular}{|l|lll|}
\hline & Journal : Small 10526 & Dispatch : $\mathbf{1 0 - 1 0 - 2 0 0 7}$ & Pages : 22 \\
& Article No. : 9125 & $\square$ LE & $\square$ TYPESET \\
MS Code : BICO632 & $\checkmark \mathrm{CP}$ & $\checkmark$ DISK \\
\hline
\end{tabular}

J. K. Pell et al.

210 Coccinellidae. However, H. axyridis interacts with many other predatory insects at the 211 community level. Lacewings (Neuroptera) are both abundant as aphid predators in natural 212 systems, and as components of biological control strategies. In a laboratory study, 213 Phoofolo and Obrycki (1998) demonstrated that there was no difference in the develop214 215 ment time or survival of $H$. axyridis (and also $C$. maculata) fed on a diet of pea aphids, Acyrthosiphon pisum (Harris) (Hemiptera: Aphididae), or eggs of the lacewing, Chrysoperla carnea (Stephens) (Neuroptera: Chrysopidae). In contrast, C. carnea was unable to develop successfully when fed on $H$. axyridis eggs.

A further study examined the interactions between adult $H$. axyridis, $C$. carnea and the gall midge Aphidoletes aphidimyza (Rondani) (Diptera: Cecidomyiidae) in the presence of the soybean aphid, Aphis glycines Matsumara (Hemiptera: Aphididae), in microcosms and field cages (Gardiner and Landis 2007). Harmonia axyridis engaged in intraguild predation with both $C$. carnea and A. aphidimyza and was predicted to contribute to declines in both species in the field. Phoofolo and Obrycki (1998) and Gardiner and Landis (2007) both suggested the potential for $H$. axyridis to be an asymmetrical intraguild predator of C. carnea. However, C. carnea will consume H. axyridis eggs (Phoofolo and Obrycki 1998) and recent observations by Fremlin (2007) indicate that $C$. carnea will also attack H. axyridis pupae. Therefore, the interaction can be considered to be (weakly) symmetrical. Further research is required to expand our knowledge on interactions between neuropterans and $H$. axyridis.

The spined soldier bug, Podisus maculiventris Say (Heteroptera: Pentatomidae) is native to North America and has a broad prey range including over 100 species of insect, primarily soft-bodied, slow-moving larvae of Coleoptera and Lepidoptera, but also aphids (McPherson 1980; Herrick and Reitz 2004). Half of the species on which it preys are important crop pests (Herrick and Reitz 2004). Podisus maculiventris is therefore loosely linked with many trophic guilds, including that of aphids (McPherson 1980; Hough-Goldstein et al. 1996), and four species of predaceous coccinellid are listed as prey to this predatory bug (McPherson 1980). In laboratory studies, Hough-Goldstein et al. (1996) demonstrated that although $P$. maculiventris did not consume adult $H$. axyridis they did consume $H$. axyridis larvae in 'no choice' treatments. In this study, $H$. axyridis larvae were described as 'aggressive' and often noted to escape predation, whereas adult $H$. axyridis were rejected, presumably as unpalatable, by $P$. maculiventris. Indeed, $P$. maculiventris took four times longer to capture $H$. axyridis larvae compared to Spodoptera frugiperda Smith (Lepidoptera: Noctuidae) larvae (Hough-Goldstein et al. 1996).

A further study demonstrated that interactions between $P$. maculiventris and $H$. axyridis in the presence or absence of extraguild prey (Spodoptera littoralis Boisduval (Lepidoptera: Noctuidae) or Myzus persicae (Sulzer) (Hemiptera: Aphididae)) were asymmetric in favour of the bug (De Clercq et al. 2003). Podisus maculiventris fed on H. axyridis eggs and larvae but rarely on adults. As with interactions amongst coccinellids, this interaction was dependent on the life stage of the bug; fourth instar nymphs and adults were more aggressive in their interactions than second instars nymphs. In contrast, $H$. axyridis rarely attacked $P$. maculiventris. Intraguild predation by $P$. maculiventris on $H$. axyridis was reduced in the presence of $S$. littoralis but not $M$. persicae. De Clercq et al. (2003) interpreted this to infer that $H$. axyridis was a less preferred prey in comparison to $S$. littoralis and this was supported by the longer development time of the bug when fed on $H$. axyridis larvae compared to $S$. littoralis. There was a slight difference in the survival to adulthood of pentatomid nymphs fed on $H$. axyridis compared to S. littoralis $(70 \%$ vs. 80-90\% respectively) and no nymphs reached adulthood when fed on just aphids (De Clercq et al. 2003). 


\begin{tabular}{|l|lll|}
\hline & Journal : Small 10526 & Dispatch : 10-10-2007 & Pages : 22 \\
& Article No. : 9125 & $\square$ LE & $\square$ TYPESET \\
MS Code : BICO632 & $\checkmark \mathrm{CP}$ & $\checkmark$ DISK \\
\hline
\end{tabular}

Intraguild predation involving $H$. axyridis

259 Intraguild predation between $H$. axyridis and parasitoids

260 Intraguild predation between predators and parasitoids is asymmetrical and can be described as both coincidental and omnivorous (Polis et al. 1989). In contrast to the literature on intraguild predation between $H$. axyridis and other predators, particularly coccinellids, there is very little information on such interactions between $H$. axyridis and parasitoids. Previous studies have reported the consumption of parasitized aphids by coccinellids (Wheeler et al. 1968; Ferguson and Stiling, 1996) and that the presence, or recent activity, of predatory coccinellids within an aphid colony can reduce the oviposition rate of aphid parasitoids (Taylor et al. 1998).

Takizawa et al. (2000) assessed whether the aphid Aphis craccivora Koch (Hemiptera: Aphididae), parasitized by Aphidius colemani Viereck (Hymenoptera: Braconidae), were suitable prey for three coccinellid species: $C$. 7-punctata, $P$. japonica and $H$. axyridis. The parasitoid was used at two life stages: 3-day-old larvae within living aphids (coincidental intraguild predation) and sessile aphid 'mummies' containing pupae (asymmetrical omnivorous intraguild predation). Consumption of parasitized aphids containing 3-day-old larvae did not reduce survival or increase development time of any of the coccinellids. In contrast, consumption of aphid 'mummies' increased the development time of all three species and reduced survival to adulthood of $C$. 7-punctata by $70 \%$ but did not affect the survival of $H$. axyridis and $P$. japonica. Coccinella 7-punctata is considered to be a more aphid-specific predator than H. axyridis (Hodek and Honek 1988). It is likely that parasitized 'mummies' are unsuitable prey and, hence, the low survival rates of C. 7-punctata fed on parasitized aphids could be attributed to their aphid-specific dietary requirements (Takizawa et al. 2000). In contrast, $H$. axyridis selectively preyed on pea aphids, $A$. pisum, rather than pea aphid 'mummies' parasitized by Aphidius ervi Haliday (Hymenoptera: Braconidae) (Snyder and Ives 2003). Although this would not change the impact of coincidental intraguild predation of larval parasitoids by $H$. axyridis, it does demonstrate that interactions are variable depending on the prey concerned. Similarly, in a study at larger spatial scales Snyder et al. (2004a) found that although H. axyridis did prey on 'mummies' of the aphid parasitoid Aphelinus asychis Walker (Hymenoptera: Aphelinidae) (adult $H$. axyridis showed no discrimination between 'mummies' and aphids although larvae preferred aphids in feeding trials), the overall parasitism level was not affected.

\section{Intraguild predation between H. axyridis and pathogens}

291 Entomopathogenic fungi are common pathogens of aphids and can be involved in both coincidental and omnivorous, asymmetrical or symmetrical, intraguild interactions (Roy and Pell 2000; Völkl et al. 2007). The most common fungal pathogens are host-specific species from the Zygomycetes, order Entomophthorales, although other species from the Ascomycetes, order Hypocreales, some with wide host ranges, are used as biopesticides and could, therefore, be involved in intraguild interactions (Powell and Pell 2007; Pell 2008).

During the final stages of infection by entomopathogenic fungi the host dies and the fungus sporulates to produce more infective propagules (conidia) for transmission (Inglis

300 et al. 2001; Pell et al. 2001). As the sporulating aphid cadaver is sessile, it is an easy prey 301 item for generalist predators. In a laboratory study, Roy et al. (2008a) assessed the pre302 dation of aphid cadavers sporulating with Pandora neoaphidis (Remaudière and 303 Hennebert) Humber (Zygomycetes: Entomophthorales) by UK and Japanese-derived 


\begin{tabular}{|l|lll|}
\hline & Journal : Small 10526 & Dispatch : $\mathbf{1 0 - 1 0 - 2 0 0 7}$ & Pages : 22 \\
& Article No. : $\mathbf{9 1 2 5}$ & $\square$ LE & $\square$ TYPESET \\
MS Code : BICO632 & $\checkmark$ CP & $\checkmark$ DISK \\
\hline
\end{tabular}

J. K. Pell et al.

304 H. axyridis relative to that of the UK native species C. 7-punctata. Unlike C. 7-punctata, 305 which showed a strong preference for aphids over sporulating fungal cadavers, $H$. axyridis showed little discrimination between the prey types and would consume whole, sporulating cadavers. The consumption of whole sporulating cadavers could remove a significant quantity of inoculum from the aphid population, which may result in a reduction in further transmission. As $P$. neoaphidis only infects aphids, this represents asymmetrical intraguild predation. The strength of intraguild predation by $H$. axyridis collected in the UK differed from those collected in Japan, with $H$. axyridis (UK) showing less discrimination between prey types compared to $H$. axyridis (Japan) (Roy et al. 2008a). Whether feeding on infected cadavers has fitness consequences for $H$. axyridis is unknown.

Other entomopathogenic fungi have wider host ranges and may be infective towards both coccinellids and aphids, making the intraguild interaction potentially symmetrical. For example, isolates of the entomopathogenic fungi Metarhizium anisopliae (Metschnikoff) Sorokin (Ascomycete: Hypocreales), Paecilomyces fumosoroseus (Wise) Brown and Smith (Ascomycetes: Hypocreales) and Beauveria bassiana (Balsamo) Vuillemin (Ascomycetes: Hypocreales) have been recorded infecting both aphids and coccinellids (e.g., Magalhaes et al. 1988; Keller and Zimmerman 1989; Butt et al. 1994; James and Lighthart 1994; Yeo 2000; Pell and Vandenberg 2002; Ormond et al. 2006). In particular, B. bassiana is a major overwintering mortality agent of C. 7-punctata (Majerus 1994; Ormond et al. 2006). Roy et al. (2008b) assessed the susceptibility of $H$. axyridis derived from the UK and Japan to $B$. bassiana relative to that of the UK native species $C$. 7-punctata and A. 2-punctata. Only doses of $10^{9}$ conidia $\mathrm{ml}^{-1}$ resulted in mortality of $H$. axyridis, in contrast, $80 \%$ of C. 7-punctata and $70 \%$ of A. 2-punctata exposed to $10^{7}$ conidia $\mathrm{ml}^{-1}$ of $B$. bassiana succumbed to infection. In addition, the results suggested that the UK derived strain may be more resistant to infection than the Japanese derived strain. Interestingly, inoculation with $B$. bassiana at a concentration as low as $10^{5}$ conidia $\mathrm{ml}^{-1}$ reduced the fecundity of $H$. axyridis (Roy et al. 2008b). Whether any of these coccinellids feed on B. bassiana-infected cadavers and the implications of this on the symmetry of intraguild predation is unknown. However, in the study of Pell and Vandenberg (2002) the coccinellid H. convergens did consume living Diuraphis noxia Kurdjumov (Hemiptera: Aphididae) aphids infected by P. fumosoroseus but did not consume sporulating aphid cadavers.

In both studies by Roy et al. (2008a, b), the interactions involving $H$. axyridis collected from the UK differed from those collected in Japan, with $H$. axyridis from the UK being a stronger intraguild predator of $P$. neoaphidis and more resistant to B. bassiana than the strain from Japan. These are the first studies to indicate fundamental differences between $H$. axyridis subpopulations and demonstrate the importance of assessing genetic and ecological variability amongst such subpopulations.

342 Intraguild predation involving $H$. axyridis: Conclusions to date

343 There is broad agreement, from the studies described above, that $H$. axyridis is a top

344 predator as it is predominantly a strong asymmetrical intraguild predator of other guild 345 members (Hironori and Katsuhiro 1997; Cottrell and Yeargan 1998; Phoofolo and Obrycki 346 1998; Yasuda and Ohnuma 1999; Michaud 2002; Sato et al. 2003, 2005; Felix and Soares 347 2004; Snyder et al. 2004b; Kajita et al., 2006; Perez and Omkar 2006; Roy et al. 2006, 348 2008a, b; Cottrell 2007; Ware and Majerus 2008) and as such can dominate in aggressive 349 intraguild interactions and lead to a decline in guild diversity. 


\begin{tabular}{|l|lll|}
\hline & Journal : Small 10526 & Dispatch : 10-10-2007 & Pages : 22 \\
& Article No. : 9125 & $\square$ LE & $\square$ TYPESET \\
MS Code : BICO632 & $\checkmark \mathrm{CP}$ & $\checkmark$ DISK \\
\hline
\end{tabular}

Intraguild predation involving $H$. axyridis

The key functional traits that make $H$. axyridis such an exceptional intraguild predator are its relatively large size, aggressive behaviour, extreme polyphagy and the possession of effective physical and chemical defence strategies. Together these traits provide the mechanism by which $H$. axyridis impacts on guilds and food webs in general (Tedders and Schaefer 1994; Hodek 1996; Yasuda and Shinya 1997; Yasuda and Ohnuma 1999; Kajita et al. 2000; Koch 2003). It therefore seems likely that $H$. axyridis could disrupt aphidophagous/coccidophagous community structure leading to declines in other species in the guild where it establishes as a non-native species. Harmonia axyridis has certainly become abundant and widely distributed as a non-native species throughout North America and Europe (Koch 2003; Brown et al. 2008) and field data from the USA has reported associated negative impacts on native coccinellid species in these regions (Elliott et al. 1996; LaMana and Miller 1996; Brown and Miller 1998; Colunga-Garcia and Gage 1998; Lucas et al. 2002; Michaud 2002; Nault and Kennedy 2003). Interestingly, C. 7-punctata was also introduced and became established widely in North America prior to the establishment of $H$. axyridis (Gordon 1985). It too displaced native coccinellids and became the dominant predator. However, $H$. axyridis is a more aggressive predator than $C$. 7-punctata; larvae of $H$. axyridis consume those of $C$. 7-punctata but the reverse occurs considerably less frequently (Hironori and Katsuhiro 1997; Yasuda et al. 2004; Ware and Majerus 2008). Since the arrival of $H$. axyridis in the USA, it has displaced C. 7-punctata as the 'top predator' demonstrating the considerable dominance of $H$. axyridis as an intraguild predator of native and exotic coccinellids alike (Snyder et al. 2004b).

Similar evidence of declines in native coccinellid species after establishment of H. axyridis is accumulating in Europe. For example, evidence suggests that in London numbers of some, but not all, native coccinellids (particularly A. 2-punctata) have declined significantly since the arrival of $H$. axyridis in 2004 (Majerus, unpublished data). This is almost certainly due to its superior competitive ability and status as an intraguild predator. From the experimental studies of Ware and Majerus (2008), with consideration of the wider ecologies of $H$. axyridis and British ladybirds, and in the absence of control or mitigation, we anticipate that aphidophagous habitat generalists such as C. 7-punctata, A. 2-punctata and P. 14-punctata will be most at risk from the establishment of H. axyridis in the UK, followed by aphidophagous habitat specialists such as Myzia oblongoguttata (L.) (Coleoptera: Coccinellidae), Myrrha 18-guttata (L.) (Coleoptera: Coccinellidae) and Anisosticta 19-punctata (L.) (Coleoptera: Coccinellidae). The only species that may be relatively unaffected by invasive $H$. axyridis is $A$. ocellata, and indeed $H$. axyridis could actually be at risk from detrimental interactions with this species where they co-inhabit coniferous woodland. It is thought that the aphidophagous specialist C. 5-punctata would be particularly threatened if $H$. axyridis invades unstable river shingle, as it is already considered of conservation concern (Ware et al. 2005). Coccidophagous species such as Exochomus 4-pustulatus (L.) (Coleoptera: Coccinellidae) and Chilocorus renipustulatus (Scriba) (Coleoptera: Coccinellidae) and the Erica/Calluna heathland specialists Chilocorus 2-pustulatus (L.) (Coleoptera: Coccinellidae) and Coccinella hieroglyphica L. (Coleoptera: Coccinellidae) are thought to be less at risk, the latter because $H$, axyridis has yet to be recorded from such heathland. Mycophagous, phytophagous and myrmecophilous coccinellids, such as Thea 22-punctata (L.) (Coleoptera: Coccinellidae), Subcoccinella 24-punctata (L.) (Coleoptera: Coccinellidae) and Coccinella magnifica Redtenbacher (Coleoptera: Coccinellidae) respectively, are likely to be the least threatened by the establishment of $H$. axyridis in Britain.

There is clear evidence for declines in diversity of coccinellids in the USA and increasingly in Europe. However, there have been no studies to evaluate impacts on the 


\begin{tabular}{|l|lll|}
\hline & Journal : Small 10526 & Dispatch : $\mathbf{1 0 - 1 0 - 2 0 0 7}$ & Pages : 22 \\
& Article No. : 9125 & $\square$ LE & $\square$ TYPESET \\
MS Code : BICO632 & $\checkmark$ CP & $\checkmark$ DISK \\
\hline
\end{tabular}

J. K. Pell et al.

399 diversity of other guild members or on biodiversity more widely; these are urgently 400 required, particularly in areas undergoing invasion by $H$. axyridis, if the full implications 401 of its presence are to be evaluated.

402 Knowledge gaps, future perspectives and implications for biodiversity 403 and ecosystem function

Harmonia axyridis is also a dominant intraguild predator in its native range, as shown by Ware and Majerus (2008) who paired Japanese H. axyridis with Japanese native coccinellids in their laboratory interaction studies and found that $H$. axyridis was the successful intraguild predator in the majority of cases. It has also prevented the establishment of the introduced coccinellid A. 2-punctata in Japan (Sakuratani et al. 2000; Kajita et al. 2006). However, it appears to co-exist with most other guild members (Kuznetsov 1997) whilst causing declines and competitive exclusion of other coccinellid species in regions where it is an invasive exotic (e.g., Colunga-Garcia and Gage 1998; Michaud 2002). In co-evolved communities that utilise limited resources, species will be under selection to either ensure that they win any competitive interaction or that they avoid competition through resourceuse complementarity and niche differentiation (Wilby and Thomas 2002a, b; Pell 2008). It is possible that, although $H$. axyridis is the top predator in its native range, other predator 416 populations can escape intraguild predation through spatial or temporal niche differenti417 ation. Studies to understand the mechanisms for co-existence with $H$. axyridis in its native range are essential if we are to mitigate existing effects in its invasive range.

\section{Temporal niche differentiation}

The co-existence of $H$. axyridis and sympatric species in Asia may, in part, be due to phenological differences that lead to temporal niche differentiation. For example, C. 7-punctata brucki is active earlier in the spring in Japan than H. axyridis and its larvae are therefore larger and more able to survive in intraguild combat with $H$. axyridis (Takahashi and Naito 1984; Sato 2001). Phenological studies of H. axyridis in its nonnative range are essential if we are to predict the extent of intraguild predation and consequent impacts on biodiversity. Such studies are underway and in the UK, for example, early indications are that $H$. axyridis emerges from winter in synchrony with most native aphidophagous coccinellids, which contributes to the latter's inability to escape intraguild predation. Harmonia axyridis is also multivoltine and remains active for longer through the season, allowing numbers of individuals to build up rapidly. All life stages of $H$. axyridis have been recorded in November (early winter) in the UK (Majerus et al. 2006; Brown et al. 2008). In one study from the USA biological control literature, Flowers et al. (2006) considered intraguild interactions amongst three exotic predators attacking the hemlock woolly adelgid, Adelges tsugae (Annand) (Hemiptera: Adelgidae) in hemlock stands in West Virginia. The species included were: specialists, Laricobius nigrinus (Fender) (Coleoptera: Derodontidae) and the coccinellid Sasajiscymnus tsugae (Sasaji \& McClure) (Coleoptera: Coccinellidae), and the generalist H. axyridis. The authors concluded that intraguild predation by $H$. axyridis was not common because they were phenologically separated and active during different seasons; L. nigrinus was most active in spring and $H$. axyridis in summer. This also has implications for the wider guild beyond other coccinellids, for which there is currently very little information. 


\begin{tabular}{|l|lll|}
\hline & Journal : Small 10526 & Dispatch : 10-10-2007 & Pages : 22 \\
& Article No. : 9125 & $\square$ LE & $\square$ TYPESET \\
& MS Code : BICO632 & $\vee$ CP & $\checkmark$ DISK \\
\hline
\end{tabular}

Intraguild predation involving $H$. axyridis

443 Other coccinellid species in $H$. axyridis' native range may escape intraguild predation through associations with ants. Although there are limited studies on myrmecophilous interactions in the native range of $H$. axyridis, it is well documented for some coccinellid species in Europe. Many aphids and coccids are myrmecophilous and gain benefits from being associated with ants, including protection from natural enemies, in exchange for food in the form of honeydew (e.g., Hölldobler and Wilson 1990; Jiggins et al. 1993; Majerus et al. 2007). There is considerable evidence to demonstrate that ants display ownership behaviour, whereby they behave more aggressively towards predators in the vicinity of tended colonies than elsewhere (Way 1963). In the case of coccinellids, this aggression may be directed toward both adults and larvae, the former being chased away (e.g., Itioka and Inoue 1996; Sloggett 1998), while the latter may be picked up and dropped off the plant, or killed (e.g., Jiggins et al. 1993; Sloggett and Majerus 2003). As a result of ant aggression, most coccinellids only feed on ant-tended prey when untended prey are scarce (Sloggett and Majerus 2000). Many coccinellids have defences against ant aggression, which may be behavioural, chemical or physical and lead to yariation in tolerance to ants amongst different coccinellid species (Majerus et al. 2007). For example, Sloggett and Majerus (2000) showed a hierarchy in six species of coccinellid living in pine woodland in the UK to aggression from Formica rufa (L.) (Hymenoptera: Formicidae) from no tolerance (M. 18-guttata and A. ocellata) to high tolerance (C. magnifica). Unfortunately, the level of tolerance of $H$. axyridis to ant aggression in either its native or its invasive range is unknown. Should $H$. axyridis be found to be intolerant of ant presence, it is likely that those aphidophages that have a significant degree of ant tolerance, such as M. oblongoguttata and C. 7-punctata, will find a refuge from some of the effects of intraguild predation and competition imposed by $H$. axyridis in habitats occupied by ant-tended aphids. Experiments to investigate the level of tolerance of $H$. axyridis to common aphid tending ants, such as F. rufa, Lasius niger (L.) (Hymenoptera: Formicidae) and Myrmica ruginodis Nylander (Hymenoptera: Formicidae), are urgently needed. The small number of coccinellid species that are true myrmecophiles, i.e., have the closest relationships with ants and associated high tolerance, are likely to have the safest refuge from $H$. axyridis, unless $H$. axyridis is also highly tolerant to ants. These species include $C$. magnifica (Sloggett et al. 2002; Majerus et al. 2007) and Platynaspis luteorubra (Goeze) (Völkl 1995; Godeau 2000). It is possible that some species that have some tolerance of ants may come under additional selection pressures to improve their tolerance as a result of the presence of $H$. axyridis. In regions now occupied by $H$. axyridis, monitoring the coccinellid presence in the vicinity of nests of $F$. rufa over the next decade would be valuable.

\section{Behavioural interactions}

Further work is also required to acquire data on behavioural defence strategies of guild members in the presence of $H$. axyridis, such as dislodgement (dropping behaviour) and escape behaviours which could be extremely important for some species. For example, larvae of the coccinellid P. 14-punctata are consumed by $H$. axyridis in laboratory studies conducted in Petri dishes, but it is speculated that the highly mobile larvae of this species may have the capability to successfully escape from H. axyridis in field situations (Ware and Majerus 2008). We also know that parasitoids and predators can use volatile and chemical 


\begin{tabular}{|l|lll|}
\hline & Journal : Small 10526 & Dispatch : $\mathbf{1 0 - 1 0 - 2 0 0 7}$ & Pages : 22 \\
& Article No. : $\mathbf{9 1 2 5}$ & $\square$ LE & $\square$ TYPESET \\
MS Code : BICO632 & $\checkmark$ CP & $\checkmark$ DISK \\
\hline
\end{tabular}

J. K. Pell et al.

487

488

489

490

491

492

493

494

495

496

497

498

499

500

501

502

503

504

505

Natural enemy release and biotype variation

507

508

509

510

511

512

513

514

515

516

517

518

519

520

521

522

523

524

525

526

527

528

529

530

531

cues to avoid competition; both the coccinellid C. 7-punctata and the predatory bug Anthocoris nemorum (L.) (Heteroptera: Anthocoridae) can detect and avoid surfaces contaminated by the fungal pathogen $B$. bassiana to which they are susceptible (Meyling and Pell 2006; Ormond 2007). In addition, the aphid parasitoid $A$. ervi detects volatiles from the tracks of C. 7-punctata and avoids oviposition in nearby aphid populations (Nakashima et al. 2004). Such behavioural responses can ensure co-existence by reducing the risk of intraguild predation. They may contribute to co-existence of $H$. axyridis in its co-evolved native guild populations and are currently being evaluated for $H$. axyridis in the broader UK guild.

Other intraguild interactions, such as facilitation, have been recorded for some species and shown to mitigate the effects of intraguild predation on guild diversity and may also apply to $H$. axyridis. For example, although $C$. 7-punctata is an intraguild predator of the aphid-specific pathogenic fungus $P$. neoaphidis, it does not consume whole, fungal cadavers and transmission of the fungus is not reduced. Indeed, C. 7-punctata enhances transmission of the fungus and passively vectors it between aphid populations, thereby also aiding pathogen dispersal (Roy et al. 1998, 2001; Roy and Pell 2000). Some of these co-evolved behavioural traits may contribute to the maintenance of guild diversity in the native range of $H$. axyridis and may mitigate its effects on some species in the invasive range. In preliminary studies, $H$. axyridis did enhance transmission and dispersal of P. neoaphidis in the laboratory (J. Baverstock personal observation).

Differences in functional traits of invasive and non-invasive biotypes of $H$. axyridis may have exacerbated their impact in non-native ecosystems. Although direct comparisons between different biotypes of $H$. axyridis and other natural enemies found in its exotic range have only been made for a limited number of functional traits, they have all demonstrated that the UK invasive biotype is a stronger asymmetric intraguild predator than the Japanese biotype. Specifically Roy et al. (2008b) demonstrated that H. axyridis from a culture derived from Japan were less likely to consume aphid cadavers supporting the beneficial aphid-specific fungal pathogen $P$. neoaphidis than those derived from the UK. They speculated that $H$. axyridis obtained from non-native populations were derived from biological control cultures and, through microevolution or founder effects, have been, perhaps unintentionally, selected for extreme polyphagy and an increased tendency towards intraguild predation compared to $H$. axyridis in its native range (Roderick and Howarth 1999; Hufbauer and Roderick 2005; Roy et al. 2008a). It would be extremely interesting to compare the strength and symmetry of intraguild interactions between Japanese, UK and US derived $H$. axyridis for a wider range of guild members, from both native and non-native ranges to determine if they function differently in relation to all guild members with which they compete. In addition, UK-derived H. axyridis have greater resistance to some natural enemies, such as the fungus $B$. bassiana and the parasitoid wasp, Dinocampus coccinellae Schrank (Hymenoptera: Braconidae) than do Japanese-derived H. axyridis, implying that they have also been released from their own population regulators (Koyama and Majerus 2008; Roy et al. 2008b). Evolution of resistance to disease, parasitism and insecticides is not uncommon in insects and may be associated with trade offs in fitness (e.g., Foster et al. 2007; Völkl et al. 2007). For example, although UK-derived $H$. axyridis were less suceptible to infection they were also significantly less fecund when infected than $B$. bassiana-infected $H$. axyridis derived from Japan (Roy et al. 


\begin{tabular}{|l|lll|}
\hline & Journal : Small 10526 & Dispatch : 10-10-2007 & Pages : 22 \\
& Article No. : 9125 & $\square$ LE & $\square$ TYPESET \\
& MS Code : BICO632 & $\vee$ CP & $\nabla$ DISK \\
\hline
\end{tabular}

Intraguild predation involving $H$. axyridis

532 2008b). Further research is needed to fully evaluate these interactions and determine

533 whether any associated fitness costs could prove to be $H$. axyridis' weakness.

\section{Going beyond managed ecosystems}

535 The focus of research has largely been on interactions between $H$. axyridis and other coccinellids in managed ecosystems and, until recently, mainly in the USA, which has very different agricultural systems to Europe. However, it is clear from the studies described above that $H$. axyridis can have impacts on many other species and that this has implications beyond managed ecosystems to natural habitats. Such impacts require urgent investigation. Harmonia axyridis is dispersive and highly polyphagous and therefore likely to impinge on many foodwebs in many different ecosystems, with the potential to disrupt them all. Although native coccinellids with similar prey and habitat requirements are at greatest risk, other non-coccinellid guild members and non-target species beyond the guild, such as Hemiptera of no economic importance (Majerus et al. 2006), lepidopteran eggs and larvae (Koch 2003; Koch et al. 2006) and all the predators, hyperparasites and pathogens in the higher trophic levels (Roy et al. 2008b) that may also be negatively affected. This represents a significant threat to biodiversity per se, particularly as some of these species are of considerable conservation concern (Koch et al. 2006).

What about scale?

550 We must also remember that many of the studies to date have been made on a small scale 551 in the laboratory. This does not detract from their value in identifying key protagonists and 'worst case scenarios': certainly, a species that is not preyed on by $H$. axyridis in a Petri dish experiment is unlikely to be at risk in the field. However, they do not consider the importance of spatial scale and habitat complexity on niche differentiation and the outcome of contests. Testing hypotheses on these subjects requires experiments to move to larger spatial and temporal scales. The work of Snyder et al. (2004a) demonstrated that, although parasitoid 'mummies' of $A$. asychis were susceptible to intraguild predation by $H$. axyridis, overall parasitism rates were unaffected when experiments were done on a larger spatial scale. It is also important to consider more complex communities, i.e. not just pairs of protagonist species but a more representative guild, if we are to determine whether diversity will decline and what implications this will have for ecosystem services.

563 Predators are part of the functional biodiversity in managed ecosystems and, while not the 564 only contributor to herbivore population regulation, they are essential for sustainable pest management through the ecosystem services they provide and that we depend upon. While the abundance of particular species can be enhanced through biological control, the question of 'how many species are required to achieve the required service in the crop?' continues to be a matter of debate (e.g., Denoth et al. 2002; Pell 2008; Straub et al. 2008) and must be considered in the context of the arrival of $H$. axyridis and potential declines in guild diversity. The relationship between predator biodiversity and ecosystem function is poorly understood. From the studies described above, and field observations of declines in 
native aphidophages and coccidophages since the arrival of $H$. axyridis, we must consider whether $H$. axyridis as a top predator, will deliver the same ecosystem service when other guild species are excluded or whether this will reduce aphid regulation (prey release) and the reliability of biological control in the long term.

Straub et al. (2008) reviewed recent literature on the relative pest suppression function of multiple (more than two) compared to single predator species and found that the relationship between predator diversity and pest suppression was context dependent and could be positive, negative or neutral. Theoretically, if increasing predator diversity encourages intraguild predation, or, as in the case of invasion by $H$. axyridis, an invasive intraguild predator is introduced to the system, then the prediction would be that the equilibrium density of the herbivore would increase and pest control function would be reduced (e.g., Polis et al. 1989; Finke and Denno 2004). Effectively, trophic cascades would be dampened and the herbivore would be released from predation. However, the experimental evidence to support this in a number of communities is mixed. Some studies have documented disruption of pest suppression and others have shown either no change or improved pest suppression in the presence of intraguild predation (Straub et al. 2008). Most recent meta-analysis by Rosenheim and Harmon (2006) and a literature review by Janssen et al. (2006) find no evidence that the presence of intraguild predation disrupts herbivore control. However, there was greater variation than expected between cases, suggesting that pest release depended on system-specific factors, such as the biological traits of the predators and prey, and extrinsic factors, such as the environment: i.e., there was no simple prediction relating intraguild predation to pest release (Straub et al. 2008).

However, Straub et al. (2008) have identified particular traits of relevance from the theoretical literature. The first relates to the life history of the intraguild prey. Coincidental intraguild predation of parasitoids and pathogens is likely to be less disruptive to herbivore suppression than omnivorous intraguild predation of other predators because predation of the herbivore and the parasitoid/pathogen are directly linked and intraguild predation will simultaneously result in predation of the herbivore (Rosenheim et al. 1995). However, this may not hold if several generations of the intraguild prey are considered (Snyder and Ives 2001). Secondly, the relative mobility and size (foraging mode) of the intraguild predator, intraguild prey and the herbivore can all influence the likelihood of prey release. A 'sit and wait' intraguild predator could disrupt suppression of a sedentary herbivore by a mobile intraguild prey species, although this will depend on the size of the intraguild prey species too. If it is large and highly mobile, it will have a large demand for prey, and if removed from the system by intraguild predation could result in release of the herbivore prey (Rosenheim and Corbett 2003). Furthermore, if the intraguild prey is a similar size to the herbivore then adding a larger intraguild predator will enhance herbivore suppression because predation of the herbivore by the intraguild predator would greatly outweigh the small release from predation achieved by the consumption of the intraguild prey (Diehl 1993). The opposite would be the case if the intraguild prey was much larger than the herbivore (Rosenheim and Corbett 2003). There is some experimental support for this 614 prediction (Rosenheim et al. 2004a, b) but for the most part they remain hypotheses that require experimental evaluation. In addition, they will be influenced by whether the top intraguild predator is co-evolved with the rest of the guild or whether it is an exotic 616 alien species, as is the case with $H$. axyridis. Using the hypotheses above, one could 617 predict from the biological traits of $H$. axyridis that it would release herbivores from 618 control because it consumes intraguild prey that are large and mobile. However, it is itself 619 large, mobile, well defended, multivoltine and highly voracious which could compensate 620 for this, at least in the short term. 


\begin{tabular}{|l|lll|}
\hline & Journal : Small 10526 & Dispatch : 10-10-2007 & Pages : 22 \\
& Article No. : 9125 & $\square$ LE & $\square$ TYPESET \\
MS Code : BICO632 & $\checkmark \mathrm{CP}$ & $\checkmark$ DISK \\
\hline
\end{tabular}

Intraguild predation involving $H$. axyridis

Within guilds of predators some species may be functionally redundant if they share traits and their function would be replaced by other species should they be lost (Wilby and Thomas 2002a, b; Ives et al. 2005; Casula et al. 2006). If there are many redundant species within a guild, then a decline in their diversity associated with the arrival of $H$. axyridis may not influence overall function. However, determining whether species are functionally redundant within a guild relies on the ability to divide them into functional groups with similar traits (e.g., prey preference, response to prey density, microhabitat use and phenology). Those with similar traits should compete strongly for resources and are, therefore, likely to be functionally redundant.

Within the aphidophagous guild there have been studies to demonstrate that increasing the number of species in the guild increases prey suppression, suggesting resource-use complementarity (Powell et al. 2006). However, other workers have shown no such effects and suggest significant redundancy of some guild members (Evans 1991; Chang 1996; Straub and Snyder 2006). The former may be more likely because the latter results could be due to negative and positive interactions between species counteracting each other (Snyder and Ives 2003) or because species that appear functionally redundant under some environmental conditions are functionally diverse when environmental conditions change (Naeem and Li 1997). This effect is encompassed in the 'insurance hypothesis' that maintains that different predators perform better or worse in particular environments and that by maintaining them all provides functional compensation and reliable pest suppression despite changing conditions (Loreau et al. 2003). This is essential in managed ecosystems that are fragmented and under constant change (Pell 2008). The multiplicity of responses to change that species from a single functional group are capable of, is critical to landscape scale ecosystem resilience (Elmquist et al. 2003). There are good examples of this in the aphid/ predator system (Pell 2008). Key aphid mortality factors, which can be parasitoids on some occasions and syrphids, ground predators or entomopathogenic fungi on other occasions, demonstrate the need for diversity as insurance for function (Krauss and Poehling 1996; Hemmati 1999; Östman et al. 2001; Powell et al. 2003, 2004; Tscharntke et al. 2005; Pell 2008). Declines in guild diversity as a result of introduction of $H$. axyridis could, therefore, reduce the resilience of pest suppression in the long term.

A single prey type, or even species, can provide multiple feeding niches that a diversity of predators can use if there is niche complementarity rather than redundancy and this is achieved by resource partitioning and facilitation amongst predators. If their is complete complementarity then predator diversity should increase pest suppression (Wilby and Thomas 2002a, b; Casula et al. 2006). There is significant evidence for resource partitioning and facilitation within the aphid/predator system (Pell 2008). For example variation between aphid species, or within a species, provides an opportunity for preference amongst predators. The coccinellid C. 7-punctata exploited red morphs of the pea aphid more than green morphs whereas the parasitoid A. ervi only attacked green morphs, effectively partitioning the resource between them (Losey et al. 1997). Coccinellid species differ in their response to prey density, some being more effective at low densities and others at high densities, which effectively separates them into complementary niches (Evans 2004; Schellhorn and Andow 2005). A further example of complementarity can be seen for the interactions between C. 7-punctata, a foliar aphid predator, and the carabid beetle Harpalus pennsylvanicus (DeGeer) (Coleoptera: Carabidae), which is restricted to foraging on the soil surface. As the coccinellid forages, it dislodges aphids that are then consumed by the ground predator, enhancing overall aphid suppression (Losey and Denno 1998). Coccinellid predators and parasitoids also facilitate transmission and dispersal of the beneficial aphid pathogen P. neoaphidis (Pell et al. 1997; Fuentes-Contreras et al. 1998; 


\begin{tabular}{|l|lll|}
\hline & Journal : Small 10526 & Dispatch : 10-10-2007 & Pages : 22 \\
& Article No. : 9125 & $\square$ LE & $\square$ TYPESET \\
MS Code : BICO632 & $\checkmark \mathrm{CP}$ & $\checkmark$ DISK \\
\hline
\end{tabular}

J. K. Pell et al.

670 Roy et al. 1998, 2001; Baverstock et al. 2005). Avoidance behaviour of parasitoids and 671 coccinellids in relation to other intraguild predators is common (Nakashima et al. 2004; 672 Meyling and Pell 2006; Ormond 2007). As already described, coccinellid species can also 673 be phenologically separated, thereby partitioning resources temporally and avoiding 674 675 competition (Takahashi and Naito 1984; Sato 2001; Flowers et al. 2006) or they can have different patch-leaving times (Sato et al. 2003). As there are numerous examples of complementarity amongst aphidophagous species, it follows that the more species there are in the guild, the greater pest suppression will be. This confirms the hypothesis that declines in guild diversity as a result of introduction of $H$. axyridis could reduce effective pest suppression.

\section{Summary}

681 Overall, the evidence suggests that predator diversity is necessary for resilient pest sup682 pression and that includes aphid and coccid control (Stiling and Cornelissen 2005; 683 Cardinale et al. 2006; Pell 2008; Straub et al. 2008). Although intraguild predation does 684 not necessarily interfere with the overall ecosystem service it can interfere with pest suppression in some systems, particularly when the intraguild prey are large compared to the extraguild prey and this is the case for $H$. axyridis. Niche complementarity is almost certainly the mechanism by which $H$. axyridis remains in equilibrium with its co-evolved native guild of predators. In its exotic range, the guild of predators are co-evolved with each other but not with $H$. axyridis and as such come into direct competition with H. axyridis. This has significant implications for predator diversity, biodiversity per se and also ecosystem services. Pest management strategies aimed at maintaining predator diversity through habitat manipulation and the diversification of our agricultural landscapes could help counter declines in predator diversity associated with the arrival of H. axyridis (e.g., Barbosa 1998; Landis et al. 2000; Gurr et al. 2004; Pell 2008). Although implications for biodiversity in natural habitats are of grave concern, it is perhaps through the manipulation of managed land, which, for example, represents $70 \%$ of land in the UK, that we have the greatest chance of optimising the environment to favour our native diversity in the presence of $H$. axyridis, thereby also protecting diversity in natural habitats. To achieve this we need robust research data to fill the gaps in knowledge identified in this paper and develop mitigation strategies.

Acknowledgements Judith K. Pell and Jason Baverstock are supported by the Department for Environment, Food and Rural Affairs of the UK (Defra). Rothamsted Research receives grant-aided support from

\section{References}

Agarwala BK, Dixon AFG (1992) Laboratory study of cannibalism and interspecific predation in ladybirds. Ecol Entomol 17:303-309

Alam N, Choi IS, Song KS, Hong J, Lee CO, Jung JH (2002) A new alkaloid from two coccinellid beetles Harmonia axyridis and Aiolocaria haexapilota. B Kor Chem Soc 23:497-499

Barbosa P (ed) (1998) Conservation biological control. Academic Press, San Diego, CA, 396 pp

Baverstock J, Alderson PG, Pell JK (2005) Influence of the aphid pathogen Pandora neoaphidis on the foraging behaviour of the aphid parasitoid Aphidius ervi. Ecol Entomol 30:665-672

Berkvens N, Bonte J, Berkvens D, Deforce K, Tirry L, De Clercq P (2008) Pollen as an alternative food for Harmonia axyridis (Pallas) (Coleoptera: Coccinellidae) Biocontrol (this volume) 


\begin{tabular}{|l|llll|}
\hline & Journal : Small 10526 & Dispatch : & $\mathbf{1 0 - 1 0 - 2 0 0 7}$ & Pages : 22 \\
& Article No. : $\mathbf{9 1 2 5}$ & $\square$ LE & $\square$ TYPESET \\
\hline
\end{tabular}

Intraguild predation involving $H$. axyridis

716

717

718

719

720

721

722

723

724

725

726

727

728

729

730

731

732

733

734

735

736

737

738

739

740

741

742

743

744

745

746

747

748

749

750

751

752

753

754

755

756

757

758

759

760

761

762

763

764

765

766

767

768

769

770

771

772

773

Brown MW, Miller SS (1998) Coccinellidae (Coleoptera) in apple orchards of eastern West Virginia and the impact of invasion by Harmonia axyridis. Entomol News 109:143-151

Brown PMJ, Roy HE, Rothery P, Roy DB, Ware RL, Majerus MEN (2008) Harmonia axyridis in Great Britain: analysis of the spread and distribution of a non-native coccinellid. Biocontrol (this volume)

Buntin GD, Bouton JH (1997) Aphid (Homoptera: Aphididae) management in alfalfa by spring grazing cattle. J Entomol Sci 32:332-342

Butt TM, Ibrahim L, Ball BV, Clark SJ (1994) Pathogenicity of the entomogenous fungi, Metarhizium anisopliae and Beauveria bassiana against crucifer pests and the honey bee. Biocontrol Sci Techn 4:207-214

Cardinale BJ, Srivastava DS, Duffy JE, Wright JP, Downing AL, Sankaran M, Jouseau C (2006) Effects of biodiversity on the functioning of trophic groups and ecosystems. Nature 443:989-992

Casula P, Wilby A, Thomas MB (2006) Understanding biodiversity effects on prey in multi-enemy systems. Ecol Lett 9:995-1004

Chang GC (1996) Comparison of single versus multiple species of generalist predators for biological control. Environ Entomol 25:207-212

Colunga-Garcia M, Gage SH (1998) Arrival, establishment, and habitat use of the multicolored Asian lady beetle (Coleoptera: Coccinellidae) in a Michigan landscape. Environ Entomol 27:1574-1580

Cottrell TE (2004) Suitability of exotic and native lady beetle eggs (Coleoptera: Coccinellidae) for development of lady beetle larvae. Biol Control 31:362-371

Cottrell TE (2007) Predation by adult and larval lady beetles (Coleoptera: Coccinellidae) on initial contact with lady beetles eggs. Environ Entomol 36:390-401

Cottrell TE, Yeargan KV (1998) Intraguild predation between an introduced lady beetle, Harmonia axyridis (Coleoptera: Coccinellidae) and a native lady beetle, Coleomegilla maculata (Coleoptera: Coccinellidae). J Kansas Entomol Soc 71:159-163

De Clercq P, Peeters I, Vergauwe G, Thas O (2003) Interaction between Podisus maculiventris and Harmonia axyridis, two predators used in augmentative biological control in greenhouse crops. Biocontrol 48:39-55

Denoth M, Frid L, Myers JH (2002) Multiple agents in biological control: improving the odds. Biol Control 24:20-30

Diehl S (1993) Relative consumer sizes and the strength of direct and indirect interactions in omnivorous feeding relationships. Oikos 68:151-157

Dixon AFG (2000) Insect predator-prey dynamics: ladybird beetles \& biological control. Cambridge University Press, Cambridge, UK

Elliott N, Kieckhefer R, Kauffman W (1996) Effects of an invading coccinellid on native cocccinellids in an agricultural landscape. Oecologia 105:537-544

Elmquist T, Folke C, Nyström M, Peterson G, Bengtsson J, Walker B, Norberg J (2003) Response diversity, ecosystem change and resilience. Front Ecol Environ 1:488-494

Evans EW (1991) Intra versus interspecific interactions of ladybeetles (Coleoptera; Coccinellidae) attacking aphids. Oecologia 87:401-408

Evans EW (2000) Morphology of invasion: body size patterns associated with establishment of Coccinella septempunctata (Coleoptera: Coccinellidae) in western North America. Eur J Entomol 97:469-474

Evans EW (2004) Habitat displacement of North American ladybirds by an introduced species. Ecology 85:637-647

Felix S, Soares AO (2004) Intraguild predation between the aphidophagous ladybird beetles Harmonia axyridis and Coccinella undecimpunctata (Coleoptera: Coccinellidae): the role of body weight. Eur J Entomol 101:237-242

Ferguson KI, Stiling P (1996) Non-additive effects of multiple natural enemies on aphid populations. Oecologia 108:375-379

Finke DL, Denno RF (2004) Predator diversity dampens trophic cascades. Nature 429:407-410

Flowers RW, Salom SM, Kok LT (2006) Competitive interactions among two specialist predators and a generalist predator of hemlock woolly adelgid, Adelges tsugae (Hemiptera: Adelgidae) in south-western Virginia. Agr Forest Entomol 8:253-262

Foster SP, Devine G, Devonshire AL (2007) Insecticide resistance. In: Harrington R, van Emden H (eds) Aphids as crop pests. CABI International, pp 261-285, 717

Fremlin M (2007) Intra-guild predation of harlequin ladybird larvae by lacewing larvae. Bull Amat Entomol Soc 66:110-116

Fuentes-Contreras E, Pell JK, Niemeyer HM (1998) Influence of plant resistance at the third trophic level: interactions between parasitoids and entomopathogenic fungi of cereal aphids. Oecologia 117:426-432 


\begin{tabular}{|l|llll|}
\hline & Journal : Small 10526 & Dispatch : & $\mathbf{1 0 - 1 0 - 2 0 0 7}$ & Pages : 22 \\
& Article No. : $\mathbf{9 1 2 5}$ & $\square$ LE & $\square$ TYPESET \\
\hline
\end{tabular}

J. K. Pell et al.

Gardiner MM, Landis DA (2007) Impact of intraguild predation by adult Harmonia axyridis (Coleoptera: Coccinellidae) on Aphis glycines (Hemiptera: Aphididae) biological control in cage studies. Biol Control 40:386-395

Godeau J-F (2000) Coccinelles amies des fourmis. 2/2/ Groupe de Travail Coccinula. Feuille de Contact 2:10-15

Gordon RD (1985) The Coccinellidae (Coleoptera) of America North of Mexico. J New York Entomol Soc 93:1-912

Gurr GM, Scarratt SL, Wratten SD, Berndt L, Irvin N (2004) Ecological engineering, habitat manipulation and pest management. In: Gurr GM, Wratten SD, Altieri MA (eds) Ecological engineering for pest management: advances in habitat manipulation for arthropods. CSIRO Publishing, pp 1-12

Hemmati F (1999) Aerial dispersal of the entomopathogenic fungus Erynia neoaphidis. PhD Thesis, University of Reading $186 \mathrm{pp}$

Hemptinne JL, Dixon AFG (2000) Defence, oviposition and sex: semiochemical parsimony in two species of ladybird beetles (Coleoptera: Coccinellidae)? A short review. Eur J Entomol 97:443-447

Herrick NJ, Reitz SR (2004) Temporal occurrence of Podisus maculiventris (Hemiptera: Heteroptera: Pentatomidae) in North Florida. Fla Entomol 87:587-590

Hironori Y, Katsuhiro S (1997) Cannibalism and interspecific predation in two predatory ladybirds in relation to prey abundance in the field. Entomophaga 42:153-163

Hodek I (1996) Food relationships. In: Hodek I, Honek A (eds) Ecology of Coccinellidae. Kluwer Academic Publishers, Dordrecht pp 143-238

Hodek I, Honek A (1988) Sampling, rearing and handling of aphid predators. In: Minks AK, Harrewijn P (eds) Aphids, their biology, natural enemies and control, Vol. 2B. Amsterdam, Elsevier, pp 311-321

Hölldobler B, Wilson EO (1990) The ants. Springer Verlag, Berlin

Holt RD, Polis GA (1997) A theoretical framework for intraguild predation. Am Nat 149:745-764

Hough-Goldstein J, Cox J, Armstrong A (1996) Podisus maculiventris (Hempitera: Pentatomidae) predation on ladybird beetles (Coleoptera: Coccinellidae). Fla Entomol 79:64-68

Huey RB, Pianka ER (1981) Ecological consequences of foraging mode. Ecology 62:991-999

Hufbauer RA, Roderick GK (2005) Microevolution in biological control: mechanisms, patterns and processes. Biol Control 35:227-239

Inglis GD, Goettel MS, Butt TM, Strasser H (2001) Use of hyphomycetous fungi for managing insect pests. In: Butt TM, Jackson C, Magan N (eds) Fungi as biocontrol agents: progress, problems and potential. CABI, Wallingford, pp 23-69

Itioka T, Inoue T (1996) The role of predators and attendant ants in the regulation of a population of the citrus mealybug Pseudococcus citriculus in a satsuma orange orchard. Appl Entomol Zool 31:195-202

Ives AR, Cardinale BJ, Snyder WE (2005) A synthesis of subdisciplines: predator-prey interactions and biodiversity and ecosystem functioning. Ecol Lett 8:102-116

James RR, Lighthart B (1994) Susceptibility of the convergent lady beetle (Coleoptera, Coccinellidae) to four entomogenous fungi. Env Entomol 23:190-192

Janssen A, Montserrat M, HilleRisLambers R, de Roos AM, Pallini A, Sabelis MW (2006) Intraguild predation usually does not disrupt biological control. In: Brodeur J, Boivin G (eds) Trophic and guild interactions in biological control. Springer, Dordrecht, The Netherlands, pp 21-44

Jiggins C, Majerus MEN, Gough U (1993) Ant defence of colonies of Aphis fabae Scopoli (Hemiptera: Aphididae), against predation by ladybirds. Brit J Entomol Nat Hist 6:129-138

Kajita Y, Takano F, Yasuda H, Agarwala BK (2000) Effects of indigenous ladybird species (Coleoptera: Coccinellidae) on the survival of an species in relation to prey abundance. Appl Entomol Zool 35:473-479

Kajita Y, Yasuda H, Evans EW (2006) Effects of native ladybirds on oviposition of the exotic species, Adalia bipunctata (Coleoptera: Coccinellidae), in Japan. Appl Entomol Zool 41:57-61

Keller S, Zimmerman G (1989) Mycopathogens of soil insects. Sci Bull 240-270

King A, Meinwald J (1996) Review of the defensive chemistry of coccinellids. Chem Rev 96:1105-1122

Koch RL (2003) The multicoloured Asian lady beetle, Harmonia axyridis: a review of its biology, uses in biological control and non-target impacts. J Ins Sci 3:32-47

Koch R, Venette R, Hutchison W (2006) Predicted impact of an exotic generalist predator on monarch butterfly (Lepidoptera: Nymphalidae) populations: a quantitative risk assessment. Biol Invasions 8:1179-1193

Koyama S, Majerus MEN (2008) Differences in attack rates of Japanese and British Dinocampus coccinellae towards sympatric and allopatric stocks of Harmonia axyridis and Coccinella septempunctata. Biocontrol (this volume)

Krauss U, Poehling HM (1996) Overwintering, oviposition and population dynamics of hoverflies (Diptera: Syrphidae) in northern Germany in relation to small and large-scale landscape structure. Acta Jutlandica 71:157-169 


\begin{tabular}{|l|llll|}
\hline & Journal : Small 10526 & Dispatch : & $\mathbf{1 0 - 1 0 - 2 0 0 7}$ & Pages : 22 \\
& Article No. : $\mathbf{9 1 2 5}$ & $\square$ LE & $\square$ TYPESET \\
\hline
\end{tabular}

Intraguild predation involving $H$. axyridis

834

835

836

837

838

839

840

841

842

843

844

845

846

847

848

849

850

851

852

853

854

855

856

857

858

859

860

861

862

863

864

865

866

867

868

869

870

871

872

873

874

875

876

877

878

879

880

881

882

883

884

885

886

887

888

889

890

891

892

893

Kuznetsov VN, (1988) The Coccinellidae of the far East in Transcaucasia. Zashchita Rastenii. 5(19) (in Russian)

Kuznetsov VN (1997) Lady beetles of the russian far east, (Memoir Series No. 1). Center for Systematic Entomology, Gainesville, FL

LaMana ML, Miller JC (1996) Field observation on Harmonia axyridis (Pallas) (Coleoptera: Coccinellidae) in Oregon. Biol Control 6:232-237

Landis DA, Wratten SD, Gurr GM (2000) Habitat manipulation to conserve natural enemies of arthropod pests in agriculture. Annu Rev Entomol 45:175-201

Loreau M, Mouquet N, Gonzales A (2003) Biodiversity as spatial insurance in heterogeneous landscapes. PNAS USA 100:12765-12770

Losey JE, Denno RF (1998) Positive predator-prey interactions: enhanced predation rates and synergistic suppression of aphid populations. Ecology 79:2143-2152

Losey JE, Vaughan M (2006) The economic value of ecological services provided by insects. Bioscience 56:311-323

Losey JE, Ives AR, Harmon J, Ballantyne F, Brown C (1997) A polymorphism maintained by opposite patterns of parasitism and predation. Nature 388:269-272

Lucas E (2005) Intraguild predation among aphidophagous predators. Eur J Entomol 102:351-364

Lucas E, Coderre D, Brodeur J (1998) Intraguild predation among aphid predators: characterization and influence of extraguild prey density. Ecology 79:1084-1092

Lucas E, Gagne I, Coderre D (2002) Impact of the arrival of adults of Harmonia axyridis on adults of Coccinella septempunctata and Coleomegilla maculata (Coleoptera: Coccinellidae). Eur J Entomol 99:457-463

Magalhaes BP, Lord JC, Wraight SP, Daoust RA, Roberts DW (1988) Pathogenicity of Beauveria bassiana and Zoophthora radicans to the coccinellid predators Coleomegilla maculata and Eriopis connexa. J Invertebr Pathol 52:471-473

Magro A, Tene JN, Bastin N, Dixon AFG, Hemptinne JL (2007) Assessment of patch quality by ladybirds: relative response to conspecific and heterospecific larval tracks a consequence of habitat similarity? Chemoecology 17:37-45

Majerus MEN (1994) Ladybirds. Harper Collins, London, 320 pp

Majerus MEN, Strawson V, Roy HE (2006) The potential impacts of the arrival of the harlequin ladybird, Harmonia axyridis (Pallas) (Coleoptera: Coccinellidae), in Britain. Ecol Entomol 31:207-215

Majerus MEN, Sloggett JJ, Godeau J-F, Hemptinne J-L (2007) Interactions between ants and aphidophagous and coccidophagous ladybirds. Popul Ecol 49:15-27

McPherson JE (1980) A list of the prey species of Podisus maculiventris (Hemiptera: Pentatomidae). Great Lakes Entomol 13:17-24

Meyling NV, Pell JK (2006) Detection and avoidance of an entomopathogenic fungus by a generalist insect predator. Ecol Entomol 31:162-171

Michaud JP (2002) Invasion of the Florida citrus ecosystem by Harmonia axyridis (Coleoptera: Coccinellidae) and asymmetric competition with a native species, Cycloneda sanguinea. Env Entomol 31:827-835

Müller CB, Brodeur J (2002) Intraguild predation in biological control and conservation biology. Biol Control 25:216-223

Musser FR, Shelton AM (2003) Bt sweet corn and selective insecticides: impacts on pests and predators. J Econ Entomol 96:71-80

Naeem S, Li S (1997) Biodiversity enhances ecosystem reliability. Nature 390:507-509

Nakashima Y, Birkett MA, Pye BJ, Pickett JA, Powell W (2004) The role of semiochemicals in the avoidance of the seven-spot ladybird Coccinella septempunctata by the aphid parasitoid, Aphidius ervi. J Chem Ecol 30:1103-1116

Nault BA, Kennedy GG (2003) Establishment of multicoloured Asian lady beetle in Eastern North Carolina: seasonal abundance and crop exploitation within an agricultural landscape. Biocontrol 48:363-378

Ormond E (2007) The overwintering interactions of the seven spot ladybird (Coccinella septempunctata) and the entomopathogenic fungus Beauveria bassiana. PhD Thesis, Anglia Ruskin University

Ormond EL, Pell JK, Thomas APM, Roy HE (2006) Overwintering ecology of Coccinella septempunctata, Beauveria bassiana and Dinocampus coccinellae. In: Rossing WAH, Eggenschwiler L, Poehling H-M (eds) Working Group "Landscape management for functional biodiversity" at Zürich-Reckenholz (Switzerland), 16-19 May 2006 IOBC/wprs Bulletin 29, pp 85-88

Östman O, Ekbom B, Bengtsson J (2001) Farming practice and landscape heterogeneity influence biological control. Basic Appl Ecol 2:365-371

Pasteels JM, Deroe C, Tursch B, Braekman JC, Daloze D, Hootele C (1973) Distribution et activités des alcaloïdes défensives des Coccinellidae. J Insect Physiol 19:1771-1784 


\begin{tabular}{|l|llll|}
\hline & Journal : Small 10526 & Dispatch : & $\mathbf{1 0 - 1 0 - 2 0 0 7}$ & Pages : 22 \\
& Article No. : $\mathbf{9 1 2 5}$ & $\square$ LE & $\square$ TYPESET \\
\hline
\end{tabular}

J. K. Pell et al.

894

895

896

897

898

899

900

901

902

903

904

905

906

907

908

909

910

911

912

913

914

915

916

917

918

919

920

921

922

923

924

925

926

927

928

929

930

931

932

933

934

935

936

937

938

939

940

941

942

943

944

945

946

947

948

949

950

951

952

953

Pell JK (2008) Ecological approaches to pest management using entomopathogenic fungi; concepts, theory, practice and opportunities. In: Ekesi S, Maniania N (ed) Research Signpost (In press)

Pell JK, Vandenberg JD (2002) Interactions among Diuraphis noxia, the fungal pathogen Paecilomyces fumosoroseus and the coccinellid Hippodamia convergens. Biocontrol Sci Tech 12:217-224

Pell JK, Pluke R, Clark SJ, Kenward MG, Alderson PG (1997) Interactions between two aphid natural enemies, the entomopathogenic fungus, Erynia neoaphidis and the predatory beetle, Coccinella septempunctata. J Invertebr Pathol 69:261-268

Pell JK, Eilenberg J, Hajek AE, Steinkraus DS (2001) Biology, ecology and pest management potential of entomophthorales. In: Butt TM, Jackson C, Magan N (eds) Fungi as biocontrol agents: progress, problems and potential. CABI International, pp 71-154, 390

Perez A, Omkar (2006) Ecology and biological control application of multicoloured Asian ladybird, Harmonia axyridis. A review. Biocontrol Sci Tech 16:111-128

Phoofolo MW, Obrycki JJ (1998) Potential for intraguild predation and competition among predatory Coccinellidae and Chrysopidae. Entomol Exp Appl 89:47-55

Polis GA (1994) Food web, trophic cascade and community structure. Aust J Ecol 19:121-136

Polis GA, Holt RD (1992) Intraguild predation-the dynamics of complex trophic interactions. TREE 7:151-154

Polis GA, Myers CA, Holt RD (1989) The ecology and evolution of intra-guild predation: potential competitors that eat each other. Annu Rev Entomol 20:297-330

Powell W, Pell JK (2007) Biological control. In: Harrington R, van Emden H (eds) Aphids as crop pests. CABI International, pp 469-513, 717

Powell W, Walters K, A'Hara S, Ashby J, Stevenson H, Northing P (2003) Using field margin diversification in agri-environment schemes to enhance aphid natural enemies. In: Rossing WAH, Poehling HM, Burgio G (eds) Landscape management for functional biodiversity. IOBC/WPRS Bulletin, 26/4, pp 123-128

Powell W, A'hara S, Harling R, Holland JM, Northing P, Thomas CFG, Walters KFA (2004) Managing biodiversity in field margins to enhance integrated pest control in arable crops ('3D Farming' Project). Project report No 356. HGCA, 226 pp

Powell W, Pell JK, Nakashima Y, Baverstock J, Birkett M (2006) Functional biodiversity of aphid natural enemies: positive intra-guild interactions. In: Rossing WAH, Poehling HM, Burgio G (eds) Landscape management for functional biodiversity. IOBC wprs Bulletin, 29(6), pp 101-104

Roderick GK, Howarth FG (1999) Invasion genetics: natural colonisations, non-indigenous species and classical biological control. In: Yano E, Matsuo K, Shiyomi M, Andow D (eds) Biological invasions of pests and beneficial organisms. National Institute of Agro Environmental Sciences, Tsukuba, Japan

Rosenheim JA (1998) Higher-order predators and the regulation of insect herbivore populations. Annu Rev Entomol 43:421-447

Rosenheim JA, Corbett SA (2003) Omnivory and the indeterminancy of predator function: can a knowledge of foraging behaviour help? Ecology 84:2438-2448

Rosenheim JA, Harmon JP (2006) The influence of intraguild predation on the suppression of a shared prey population: an empirical assessment. In: Brodeur J, Boivin G (eds) Trophic and guild interactions in biological control. Springer, Dordrecht, The Netherlands, pp 1-20

Rosenheim JA, Kaya HK, Ehler LE, Marois JJ, Jaffee BA (1995) Intraguild predation among biological control agents: theory and evidence. Biol Control 5:303-335

Rosenheim JA, Glik TE, Goeriz RE, Ramert B (2004a) Linking a predator's foraging behaviour with its effects on herbivore population suppression. Ecology 85:3362-3372

Rosenheim JA, Limburg DD, Colfer RG, Fournier V, Hsu CL, Leonardo TE, Nelson EH (2004b) Herbivore population suppression by an intermediate predator, Phyoseiulus macropilis, is insensitive to the presence of an intraguild predator: an advantage of small body size? Oecologia 140:577-585

Roy HE, Pell JK (2000) Interactions between entomopathogenic fungi and other natural enemies: implications for biological control. Biocontrol Sci Tech 10:737-752

Roy HE, Pell JK, Clark SJ, Alderson PG (1998) Implications of predator foraging on aphid pathogen dynamics. J Invertebr Pathol 71:236-247

Roy HE, Pell JK, Alderson PG (2001) Targeted dispersal of the aphid pathogenic fungus Erynia neoaphidis by the aphid predator Coccinella septempunctata. Biocontrol Sci Tech 11:99-110

Roy HE, Brown P, Majerus MEN (2006) Harmonia axyridis: a successful biocontrol agent or an invasive threat? In: Eilenberg J, Hokkanen H (eds) An ecological and societal approach to biological control. Kluwer Academic Publishers, Netherlands

Roy HE, Baverstock J, Ware RL, Clark SJ, Majerus MEN, Baverstock KE, Pell JK (2008a). Intraguild predation of the aphid pathogenic fungus Pandora neoaphidis by the invasive coccinellid Harmonia axyridis. Ecol Entomol (In press) 


\begin{tabular}{|l|llll|}
\hline & Journal : Small 10526 & Dispatch : & $\mathbf{1 0 - 1 0 - 2 0 0 7}$ & Pages : 22 \\
& Article No. : $\mathbf{9 1 2 5}$ & $\square$ LE & $\square$ TYPESET \\
\hline
\end{tabular}

Intraguild predation involving $H$. axyridis

Roy HE, Brown PMJ, Rothery P, Ware RL, Majerus MEN (2008b) Effect of Beauveria bassiana on the survival and fecundity of three species of ladybird: Harmonia axyridis, Coccinella septempunctata and Adalia bipunctata. Biocontrol (this volume)

Sakuratani Y, Marsumoto Y, Oka M, Kubo T, Fuji A, Uotani M, Teraguchi T (2000) Life history of Adalia bipunctata (Coleoptera: Coccinellidae) in Japan. Eur J Entomol 97:555-558

Sato S (2001) Ecology of ladybirds: factors influencing their survival. PhD Thesis, University of East Anglia, UK

Sato S, Dixon AFG (2004) Effect of intraguild predation on the survival and development of three species of aphidophagous ladybirds: consequences for invasive species. Agr Forest Entomol 6:21-24

Sato S, Dixon AFG, Hironori Y (2003) Effect of emigration on cannibalism and intraguild predation in aphidophagous ladybirds. Ecol Entomol 28:628-633

Sato S, Yasuda H, Evans EW (2005) Dropping behaviour of larvae of aphidophagous ladybirds and its effect on incidence of intraguild predation: interactions between the intraguild prey, Adalia bipunctata (L.) and Coccinella septempunctata (L.), and the intraguild predator, Harmonia axyridis Pallas. Ecol Entomol 30:220-224

Schellhorn NA, Andow D (2005) Response of coccinellids to their aphid prey at different spatial scales. Popul Ecol 47:281-288

Sengonca C, Frings B (1985) Interference and competitive behaviour of the aphid predators, Chrysoperla carnea and Coccinella septempunctata in the laboratory. Entomophaga 30:245-251

Sloggett JJ (1998) Interactions between Coccinellids (Coleoptera) and ants (Hymenoptera: Formicidae), and the evolution of Myrmecophily in Coccinella magnifica Redtenbacher. $\mathrm{PhD}$ thesis, University of Cambridge

Sloggett JJ, Majerus MEN (2000) Aphid-mediated coexistence of ladybirds (Coleoptera: Coccinellidae) and the wood ant Formica rufa: seasonal effects, interspecific variability and the evolution of a coccinellid myrmecophile. Oikos 89:345-359

Sloggett JJ, Majerus MEN (2003) Adaptations of Coccinella magnifica, a myrmecophilous coccinellid to aggression by wood ants (Formica rufa group). II. Larval behaviour, and ladybird oviposition location. Eur J Entomol 100:337-344

Sloggett JJ, Völkl W, Schulze W, von der Schulenberg JH, Majerus MEN (2002) The ant-associations and diet of the ladybird Coccinella magnifica (Coleoptera : Coccinellidae). Eur J Entomol 99:565-569

Snyder WE, Evans EW (2006) Ecological effects of invasive arthropod generalist predators. Annu Rev Ecol Evol S 37:95-122

Snyder WE, Ives AR (2001) Generalist predators disrupt biological control by a specialist parasitoid. Ecology 82:705-716

Snyder WE, Ives AR (2003) Interactions between specialist and generalist natural enemies: parasitoids, predators and pea aphid biocontrol. Ecology 84:91-107

Snyder WE, Ballard SN, Yang S, Clevenger GM, Miller TD, Ahn JJ, Hatten TD, Berryman AA (2004a) Complementary biocontrol of aphids by the ladybird beetle Harmonia axyridis and the parasitoid Aphelinus asychis on greenhouse roses. Biol Control 30:229-235

Snyder WE, Clevenger GM, Eigenbrode SD (2004b) Intraguild predation and successful invasion by introduced ladybird beetles. Oecologia 140:559-565

Stiling P, Cornelissen T (2005) What makes a successful biological control agent? A meta-analysis of biological control agent performance. Biol Control 34:236-246

Straub CS, Snyder WE (2006) Experimental approaches to understanding the relationship between predator diversity and conservation biological control. In: Brodeur J, Boivin G (eds) Trophic and guild interactions in biological control. Springer, Dordrecht, The Netherlands, pp 221-239

Straub CS, Finke DL, Snyder WE (2008) Are the conservation of natural enemy biodiversity and biological control compatible goals? Biol Control (In press)

Takahashi K, Naito A (1984) Seasonal occurrence of aphids and their predators (Col. Coccinellidae) in alfalfa fields. Bulletin of the National Grassland Research Institute 29:62-66 [In Japanese with English summary]

Takizawa T, Yasuda H, Agarwala BK (2000) Effect of three species of predatory ladybirds on oviposition of aphid parasitoids. Entomol Sci 3:465-469

Taylor AJ, Müller CB, Godfray HCJ (1998) Effect of aphid predators on oviposition behaviour of aphid parasitoids. J Insect Behav 11:297-302

Tedders WL, Schaefer PW (1994) Release and establishment of Harmonia axyridis (Coleoptera: Coccinellidae) in the south-eastern United States. Entomol News 105:228-243

Tscharntke T, Klein AM, Kruess A, Steffan-Dewenter I, Thies C (2005) Landscape perspectives on agricultural intensification and biodiversity-ecosystem service management. Ecol Lett 8:857-874 


\begin{tabular}{|l|lll|}
\hline & Journal : Small 10526 & Dispatch : 10-10-2007 & Pages : 22 \\
& Article No. : 9125 & $\square$ LE & $\square$ TYPESET \\
MS Code : BICO632 & $\checkmark \mathrm{CP}$ & $\checkmark$ DISK \\
\hline
\end{tabular}

J. K. Pell et al.

1013

1014

1015

1016

1017

1018

1019

1020

1021

1022

1023

1024

1025

1026

1027

1028

1029

1030

1031

1032

1033

1034

1035

1036

1037

1038

1039

1040

1041

1042

1043

1044

1045

1046

1047

1048

1049
Völkl W (1995) Behavioural and morphological adaptations of the coccinellid, Platynaspis luteorubra for exploiting ant-attending resources (Coleoptera: Coccinellidae). J Insect Behav 8:653-670

Völkl W, Mackauer M, Pell JK, Brodeur J (2007) Predators, parasitoids and fungal pathogens. In: Harrington R, van Emden H (eds) Aphids as crop pests. CABI International, pp 187-233, 717

Ware RL, Majerus MEN (2008) Intraguild predation of immature stages of British and Japanese coccinellids by the invasive ladybird Harmonia axyridis. Biocontrol (this volume)

Ware RL, Majerus MEN, Roy HE, Symington F (2005) The harlequin ladybird arrives in Britain: a threat to our native species? Bull Amat Ent Soc 64:175-186

Ware RL, Evans N, Malpas L, Michie LJ, O’Farrell K, Majerus MEN (2008a) Intraguild predation by the invasive ladybird Harmonia axyridis: 1. British \& Japanese coccinellid eggs. Neobiota (In press)

Ware RL, Ramon-Portugal F, Magro A, Hemptinne JL, Majerus, MEN (2008b) Chemical protection of Calvia 14-guttata eggs against intraguild predation by the invasive ladybird Harmonia axyridis. Biocontrol (this volume)

Way MJ (1963) Mutualism between ants and honey-dew producing Homoptera. Annu Rev Entomol 8:307344

Wells ML, McPherson RM (1999) Population dynamics of three coccinellids in flue-cured tobacco and functional response of Hippodamia convergens (Coleoptera: Coccinellidae) feeding on tobacco aphids (Homoptera: Aphididae). Environ Entomol 28:768-773

Wells ML, McPherson RM, Ruberson JR, Herzog GA (2001) Coccinellids in cotton: population response to pesticide application and feeding response to cotton aphids (Homoptera: Aphididae). Environ Entomol 30:785-793

Wheeler AG, Hayes JT, Stephens JL (1968) Insect predators of mummified aphids. Can Entomol 100:221-222

Wilby A, Thomas MB (2002a) Natural enemy diversity and pest control: patterns of pest emergence with agricultural intensification. Ecol Lett 5:353-360

Wilby A, Thomas MB (2002b) Are the ecological concepts of assembly and function of biodiversity useful frameworks for understanding natural pest control? Agr Forest Entomol 4:237-243

Yasuda H, Ohnuma N (1999) Effect of cannibalism and predation on the larval performance of two ladybird beetles. Ent Exp Appl 93:63-67

Yasuda H, Shinya Y (1997) Cannibalism and interspecific predation in two predatory ladybirds in relation to prey abundance in the field. Entomophaga 42:153-163

Yasuda H, Kikuchi T, Kindlmann P, Sato S (2001) Relationships between attacks and escape rates, cannibalism, and intraguild predation in larvae of two predatory ladybirds. J Ins Behav 14:373-384

Yasuda H, Evans EW, Kajita Y, Urakawa K, Takizawa T (2004) Asymmetric larval interactions between introduced and indigenous ladybirds in North America. Oecologia 141:722-731

Yeo H (2000) Mycoinsecticides for aphid management: a biorational approach. PhD Thesis, University of Nottingham 308 pp 